Dicle Tıp Dergisi / Dicle Med J (2019) 46 (4) : 877-880

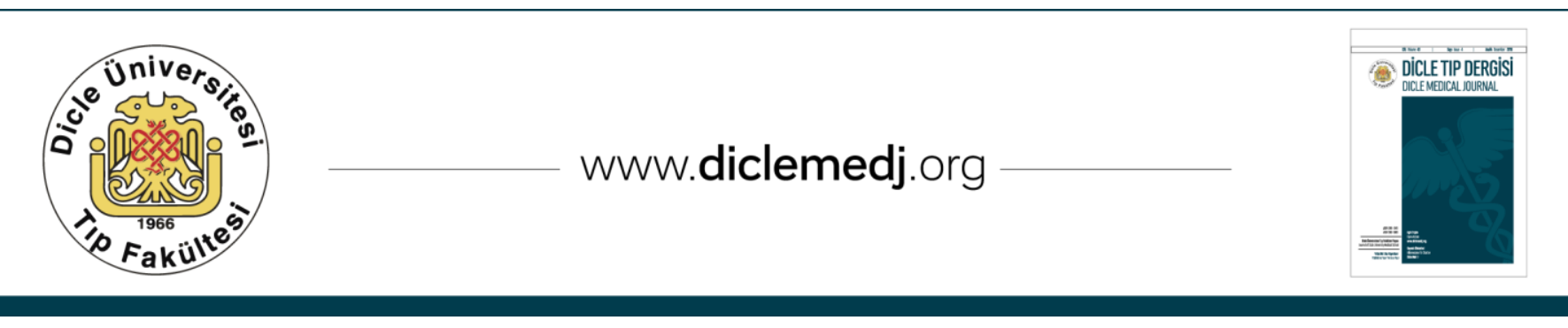

Olgu Sunumu / Case Report

\title{
An Unusual Localization of Leiomyoma: Vaginal Leiomyoma
}

\author{
Melike Demir Çaltekin'1, Taylan Onat², Demet Aydoğan Kırmızi³ ${ }^{3}$ Emre Başer ${ }^{4}$ \\ 1 Department of Obstetric and Gynecology, Bozok University Faculty of Medicine, Yozgat, Turkey ORCID: 0000-0001-8797-7794 \\ 2 Department of Obstetric and Gynecology, Bozok University Faculty of Medicine, Yozgat, Turkey ORCID: 0000-0002-8920-1444 \\ 3 Department of Obstetric and Gynecology, Bozok University Faculty of Medicine, Yozgat, Turkey ORCID: 0000-0001-7849-8214 \\ 4 Department of Obstetric and Gynecology, Bozok University Faculty of Medicine, Yozgat, Turkey ORCID: 0000-0003-3828-9631
}

Received: 17.05.2019; Revised: 29.07.2019; Accepted: 05.08.2019

\begin{abstract}
Although fibroids are very common in women with reproductive age, vaginal leiomyomas are very rare. Two patients presented to our clinic and diagnosed with atypical localization of myoma uteri. A 52-year-old woman admitted to our clinic with the complaint of menometroragia and a 45-year-old woman referred to our clinic from another center with the diagnosis of cystocele.

This two patients diagnosed as vaginal myoma. Vaginal leiomyoma may present with clinical symptoms such as dyspareunia and vaginal mass, vaginal discharge or mimicking uterovaginal prolapse. When a vaginal mass is detected, a differential diagnosis of leiomyoma should be considered despite being a rare situation.
\end{abstract}

Keywords: Leiomyoma; vaginal mass; vaginal localization

\section{Nadir Yerleşimli Leiomyom Olgusu: Vajinal Leiomyoma}

$\ddot{0} \mathbf{z}$

Leiomyomlar reprodüktif dönemdeki kadınlarda çok sık görülmesine rağmen vajinal leiomyomlar çok nadir görülür. Kliniğimize farklı şikayetlerle başvuran iki hastada vajinal leomyoma tespit edildi. 52 yaşında kadın hasta kliniğimize menometroraji şikayeti ile başvurdu ve 45 yaşında kadın hasta kliniğimize sistosel tanısı ile başka bir merkezden yönlendirildi. Bu iki hasta vajinal miyom tanısı aldı. Vajinal leiomyom; disparoni, vajinal kitle,vajinal akıntı veya uterovaginal prolapsusu taklit eden klinik semptomlarla ortaya çıkabilir. Bir vajinal kitle tespit edildiğinde, nadir görülmesine rağmen ayırıcı tanıda leiomyom da olabileceği düşünülmelidir.

Anahtar kelimeler: Leiomyom; vajinal kitle; vajinal lokalizasyon.

DOI: $10.5798 /$ dicletip.

Yazışma Adresi / Correspondence: Melike Demir Çaltekin, Department of Obstetric and Gynecology, Bozok University Faculty of Medicine, Yozgat, Turkeye-mail: melike_deu@hotmail.com 


\section{INTRODUCTION}

Leiomyoma develops from the smooth muscle of the uterus and is the most common tumor in women of reproductive age. These tumors occur almost half of women over the age of 35 years. Its prevalence increases during the reproductive age and decreases after menopause due estrogen. Their dimensions vary from microscopic to giant ones.

Leiomyomas are most commonly seen in the uterus; however, since it is formed through the proliferation of smooth muscle cells, it can develop from each tissue where these cells are present. Leiomyomas are rarely seen in the vulva, ovaries, bladder and urethra except the uterus [1]. We want to present two vaginal leiomyomas cases which are very rarely seen.

\section{CASE 1}

A 52-year-old woman, gravida 3, parity 3, admitted to our clinic with the complaint of menometroragia. There was no history of any chronic disease or drug use in her anamnesis. The patient had never undergone surgery. There was an episiotomy history in her obstetric anamnesis. General physical examination was evaluated as normal. In gynecological evaluation; in transvaginal ultrasonography uterine sizes showed an increase and there was an intramural myoma which is $13 \times 10 \mathrm{~cm}$ in size. In the speculum examination, the cervix was multiparous and semi mobile mass of approximately $3 \times 3 \mathrm{~cm}$ was detected at anterior vaginal wall. It had no association with uterus (Figure 1A). But the patient had no complaints related to this myoma. Informed consent form obtained from the patient.

The operation was planned for menometrorrhagia and vaginal mass. No pathology was found in the smear and endometrial specimens taken before the operation. In the lithotomic position, the vaginal mass was removed after urethral catheterization (Figure 1B,1C). Then, total abdominal hysterectomy was performed. The patient, experiencing no trouble in follow-ups, was discharged on the second postoperative day. The pathology results of the materials were reported as uterine leiomyoma and vaginal leiomyoma.

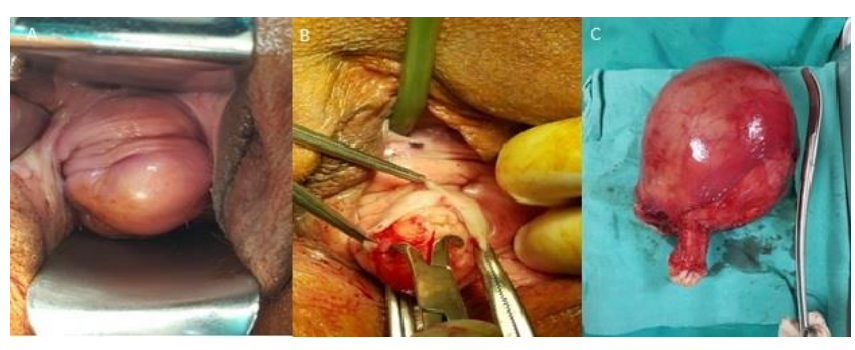

Figure 1: A. Approximately $3 \times 3.5 \mathrm{~cm}$ semi mobile mass, having no association with uterus, extending from the vagina anterior wall to the introitus. B. Vaginal Excision of mass. C. Myomato uterus specimen of the same patient after hysterectomy. (Permission was taken from the patient for the withdrawal and publication of the photos)

\section{CASE 2}

A 45-year-old gravida woman, 2 para 2, referred to our clinic from another center with the diagnosis of cystocele. Her complaint was bulging and discomfort feeling in the vagina. She has no complaint about urinary incontinance or vaginal bleeding. There was no history of any other disease or drug use. There was no any pathology about uterus and adnexes in the transvaginal ultrasonography. Speculum examination showed a bulging of about $3 \times 3,5 \mathrm{~cm}$ on the anterior vaginal wall. When the bulging was palpated, solid semimobil mass about $3.5 \mathrm{~cm}$ in size was noticed. It looked more like fibroid than cystocele. The mass was removed by operation after urethral catheterization. The pathology result of the material was reported as vaginal leiomyoma. Informed consent form obtained from the patient. 


\section{DISCUSSION}

The uterus is a common site of development of leiomyoma. Also atypically fibroids can occur outside the pelvic region such as the on abdominal wall, anterior abdominal sheath, vaginal wall or even on the chest wall ${ }^{2-4}$ Vaginal leiomyomas are very rare. Approximately 300 cases have been reported in the literature ${ }^{5}$. Although rarely seen, the most common mesenchymal tumor of the vagina is leiomyomas. Sizes can be between $0.5-15 \mathrm{~cm}$. Although it is seen everywhere in the vagina, it is most common originated from the midline of anterior vaginal wall as seen in our cases ${ }^{6}$. Tumors originating from the lateral wall have also been reported ${ }^{7}$. Although the myomas seen in vagina is primarily originated from vagina, some parasitic leiomyomas can be inoculated here.

It has been reported that vaginal leiomyoma cases can be seen from puberty to age 71 . Diagnosis is most common in the early 40's with late age of 30 years. Leiomyomas usually appear in single and small sizes and grow slowly. Some cases may be seen after hysterectomy 8,9 . As well as being asymptomatic, symptoms such as dyspareunia, pain and dysuria may be seen. The most common gynecological complaint is dyspareunia. But many patients only describe the discomfort feeling in the vagina. Vaginal leiomyoma can also mimicking uterovaginal prolapse as in our second case. In such cases, it is essential to try to identify the anatomy of displaced mass. Vaginal and rectal examination should be performed during preoperative evaluation to differentiate prolapse from cervical or uterine leiomyoma ${ }^{10}$.

The suspicion of malignancy in vaginal masses should not be forgotten, but it should also be kept in mind that may be necrosis and degeneration in vaginal myoma ${ }^{11}$. In evaluation of some cases, imaging methods can be used. In large and protruding periurethral leiomyomas, there are limitations of sonography. Magnetic resonance (MR) contributes to the preoperative characterization of the masses due to their multiplanar imaging ability and excellent soft tissue contrast. In our case, vaginal mass was considered to be benign because the mass was mobile and its borders were evaluated clearly and originating from the vesicovaginal area. Therefore, no additional imaging method was needed.

Surgical treatment is generally preferred for these tumors with vaginal approach. However, large tumors may require combined abdominal and perineal approach ${ }^{7}$. There is usually a determined cleavage, hence, surgery with minimal bleeding is safe. Although urethral damage is not reported in the literature, urethral catheterization is recommended during surgery to prevent urethral injury ${ }^{11}$.

Vaginal leiomyoma may present with clinical symptoms such as dyspareunia and vaginal mass or mimicking uterovaginal prolapse. As a result, when a vaginal mass is detected, a differential diagnosis of leiomyoma should be considered despite being a rare situation.

Declaration of Conflicting Interests: The authors declare that they have no conflict of interest.

Financial Disclosure: No financial support was received.

\section{REFERENCES}

1. Fasih N, Prasad Shanbhogue AK, Macdonald DB, et al. Leiomyomas beyond the uterus: unusual locations, rare manifestations. Radiographics. 2008; 28: 1931-48.

2. Hamzan MI. Ishak A. Basiron N. Primary Anterior Abdominal Wall Leiomyoma - A Rare Case with a Common Approach. Gynecol Obstet Reprod Med 2019; 25: 000-000.

3. Batihan G, Usluer O, Kaya SO, Aydogdu Z. Atypical deep somatic soft-tissue leiomyoma of extrathoracic chest wall: first case of the literature. BMJ Case Rep. 2018; 11: e226668.

4. Sel G. Case of an atypical located leiomyoma arising from rectus sheath. J Surg Med. 2018; 2: 408-9. 
5. Cobanoglu O, Gurkan Zorlu C, Ergun Y, Kutluay L. Leiomyosarcoma of the vagina. Eur J Obst Gynecol Reprod Biol. 1996; 70: 205-7.

6. Sherer DM, Cheung W, Gorelick C, et al. Sonographic and magnetic resonance imaging findings of an isolated vaginal leiomyoma. Journal of ultrasound in medicine: official journal of the American Institute of Ultrasound in Medicine. 2007; 26: 1453.

7. Gowri R, Soundararaghavan S, Oumachigui A, Sistla SC, Iyengar KR. Leiomyoma of the vagina: an unusual presentation. Journal of obstetrics and gynaecology research. 2003; 29: 395-8.

8. Nidhanee SV, Maiti S, Shareef D, Holland N. An unusual presentation of a vaginal leiomyoma in a postmenopausal hysterectomised woman: a case report. Cases journal. 2009; 2: 6461.
9. Yarcı A, Bayramov V, Şükür YE, Yüce T, Berker B. Vaginal vault leiomyoma: 25 years after total abdominal hysterectomy. Journal of minimally invasive gynecology. 2010; 17: 116-7

10. Malik S, Mahendru R, Rana SS. Vaginal leiomyoma presenting as dysfunctional uterine bleeding. Taiwanese Journal of Obstetrics and Gynecology. 2010; 49: 531-2.

11. Sim $\mathrm{CH}$, Lee JH, Kwak JS, Song SH. Necrotizing ruptured vaginal leiomyoma mimicking a malignant neoplasm. Obstetrics \& gynecology science. 2014; 57: 560-3. 